\title{
The Global Crisis and the Crisis of Democracy: A Cosmopolitan Way Forward?
}

\author{
Ferenc Miszlivetz (Corresponding author) \\ Institute of Political Sciences, Center for Social Sciences, Hungarian Academy of Sciences \\ Országház u. 30, H-1014, Pf.20. H-1250, Budapest, Hungary \\ Tel: 36-1-354-0920Ｅ-mail: fmiszlivetz@ises.hu
}

Jody Jensen

Institute of Political Sciences, Center for Social Sciences, Hungarian Academy of Sciences

Országház u. 30, H-1014, Pf.20. H-1250, Budapest, Hungary

Tel: 36-1-354-0920Ｅ-mail: jodyjensen@ises.hu

Received: January 25, 2013

Accepted: February 27, 2013

Online Published: March 7, 2013

doi:10.5430/rwe.v4n1p60

URL: http://dx.doi.org/10.5430/rwe.v4n1p60

\begin{abstract}
Trapped in the logic of the nation-state paradigm, political imagination and analysis remain largely restricted. Even if capable of recognizing problems, without adequate cognitive frames, the capacity to provide solutions or identify alternatives is lost. When trying to identify the deeper roots and interconnectedness of different sorts of crises (global financial, economic and debt crises, and the ecological crisis), the relationship between globalization and democracy and democratic legitimacy needs more careful analysis at the EU level. The global crisis and transformation might enhance transnational and global consciousness and responsibility-taking as well as networking and participation. An unexpected result may open the way for de facto cosmopolitanism. Given the strong political attempts and interests to re-strengthen the nation-state, the non-linear path will be conflict ridden.
\end{abstract}

Keywords: Nation-state, Globalization, Crisis, Democracy, Civil society, Cosmopolitanism

\section{Crisis Symptoms and the Emerging New Age of Uncertainties}

[There has been a shift] in the character and goals of international society: away from minimalist goals of co-existence towards the creation of rules and institutions that embody notions of shared responsibilities, that impinge heavily on the domestic organization of states, that invest individuals and groups within states with rights and duties, and that seek to embody some notion of the planetary good. (Hurrell 1995: 139)

The social sciences are criticized for failing to predict fundamental social, political and economic upheavals in the past in the case of 1989/91, and the outbreak of global financial and economic crisis in 2007/2008, and most recently in the case of the Arab Spring and the Occupy! movements. Trapped in the logic of the nation-state paradigm, political imagination and analysis remain largely restricted. Even if capable of recognizing problems, without adequate cognitive frames, the capacity to provide solutions or identify alternatives is lost. In this context, potential solutions, therapies or aspirations are considered as utopian or idealistic; and political actions organized around them are widely viewed as the 'politics of impossibility' (Falk 2012).

In turbulent times often repeated clichés and conventional wisdoms quickly become obsolete and are forgotten. For example, we know very well today that counter to Fukuyama's prediction neither history nor politics is over. If anything is over, or at least seriously discredited, it is the neo-liberal credo with all of its various social, economic, political and cultural implications. As Joseph Stiglitz (2010: ix) points out: "The crisis exposed deep flaws in notions of market fundamentalism, the theory that unfettered markets would lead to efficient and stable outcomes. So too the idea that markets could be self-regulating was shown to be the oxymoron that it was." The present global crisis is not just the result of failures in the system, but of the system itself, its organization and principles, including its flawed institutional mechanisms. 
The almighty dogma of market fundamentalism supported by media moguls and their global empires is increasingly rejected by both populist (often radical and extremist) movements on the one hand, and an emerging global civil society movement with its semi-latent networks and often less than transparent NGO-world, on the other. But the sudden collapse of firm beliefs and the erosion of powerful ideologies are only one the by-products of a deepening and increasingly manifold global crisis (Kaldor, Held, Quah 2010). As Immanuel Wallerstein has convincingly argued, it is part of a fundamental and irreversible transformation of the modern capitalist world system whose outcome is unknown (Miszlivetz 2010). The path of this undetermined period of transformation deserves more careful attention, investigation and most importantly a new frame for interpretation. It needs changing the way we look at the world - in other words a 'paradigm shift', as many suggest. When trying to identify the deeper roots and interconnectedness of different sorts of global financial, economic and debt crisis, the ecological crisis, the crisis of the EU and the Euro-zone, and most recently and virulently the crisis of democracy and legitimacy, we need to find a new global perspective to replace that of the territorially confined nation-state.

Neither understanding the roots and interdependencies of the growing complexity, nor finding solutions or alternatives is possible from the perspective of restricted and particularistic national sovereignty. When we look for alternatives we also need to identify new players. New frames assume new actors, in other words, new structures need new agency. The stubborn and hydra-headed global crisis, and the unexpected explosion of Middle-East dictatorships culminating in Arab revolutions, provoked a new genre of transnational - both regional and global discourse and consciousness that might strengthen cosmopolitan 'stakeholdership' and public opinion; perhaps even a new identification, we might cautiously call cosmopolitan citizenship.

The crisis of democracy as a set of legal regulations, procedures and institutions is one of the major and most outstanding and surprising symptoms of the current transformation. The entire set of institutional structures might disappear or get lost in the labyrinths of the global transformation, whereas new forms, structures, procedures, players and institutions might emerge. From Spain and Portugal via Greece to Turkey, from the new East Central European EU member states to Russia, from Scandinavia via Ireland and Great Britain to the United States, we see a worsening of life conditions. These include increasing uncertainties and pessimism about the future and decreasing trust in political parties and public institutions. There is a growing understanding of the crisis of democracy in general, or about 'the crisis of capitalist democracy' (Posner 2010), or about 'the crisis of parliamentary democracy' (Gilbert 2009). Even global market players and international guardian institutions such as the IMF have begun to worry about the vulnerability of democracy defined, confined and displayed by national politics. However, most of the warning signs are described in terms of symptoms and do not provide proper diagnoses and, therefore, suggested 'therapies' remain superficial, short term-oriented and ineffective. They clearly fail to satisfy an increasingly concerned public as they are unable to provide neither credible nor acceptable financial/economic, or institutional/procedural action beyond the boundaries and political perspective of the sovereign nation-state.

One of the roots of the present crisis of democracy, we believe, can be found in the increasingly unequal and imbalanced relationship between representatives of markets, governments and societies - in Marc Nerfin's words between the Merchant, the Prince and the Citizen (Nerfin 1987). (Note 1) As Robert Reich observed, present day 'supercapitalism' has "invaded democracy: capitalism has become more responsive to what we want as individual purchasers of goods, but democracy has grown less responsive to what we want as citizens" (Reich 2008: 42). Behind the current symptoms lie various less obvious but profound contradictions and ambiguities such as the tension between the global and the local, between non-territoriality and territoriality, exclusion and. inclusion, accountability on the local level versus unaccountability on the supranational level, democracy as an idea versus democracy as a set of legal procedures and formal institutions.

Perhaps most important is the tension between the territorially limited sovereign states, constrained by the de facto hierarchy of geopolitics of dominant states, on the one hand, and the unaccountability and lack of transparency of monopolistic global market players, on the other. This long-existing contradiction has produced new tensions as well as new social and political responses during the past decades. These new developments have thrown light on the non-sustainability and deeply undemocratic character of the present, in our interpretation, neo-liberal global economic, financial and institutional system and, against promises and expectations, have clearly revealed the inadequacy and weaknesses of both global and EU governance.

\section{Global Economic and Financial Meltdown and Its Consequences for Democracy}

Many critics of economic globalization claim the processes of cross-border trade and investment together with cross-border capital markets operating within de-regulated markets undermine both national sovereignty and political democracy (Holton 2010). 
Until very recently, social science theory paid little attention to the relationship between globalization and democracy. Trans-national, cross-border connections and interdependencies may automatically advance globalization further in some aspects (economic and technological) while not as much in others (politics and regulation, governance in general, citizenship and social welfare). In the case of the EU, political integration is lagging behind economic and market integration. For citizens at the national level there is no immediate political redress for market and regulatory failures through a system of EU-level political institutions. Business remains organized and regulated within a complex, opaque confusion of national, regional and global regimes that elude or obstruct democratic accountability. In addition, financial markets operate in nanoseconds $24 / 7$, facilitated by information technology. Democracy, even at just the national level (let alone the EU level), however, operates across days, months and years. This mismatch of scopes and speeds creates enormous tensions, helplessness and uncertainty on all levels of existence. (Holton 2010, Miszlivetz 2012). Resolution of this cognitive dissonance requires both greater transparency of global finance and its mechanisms and a greater commitment of financial actors to become more responsive to the claims of civil society and its democratic aspirations and demands for dignity. Both markets and states have largely failed to perform according to these expectations. If the situation is not resolved it will continue to produce dysfunctional consequences including increasing social unrest and "It is only through robust debate among people who see the world through different lenses that the validity of different perspectives can be assessed." (Stiglitz 2010: xxi)

\subsection{The Idea of Democracy vs the Praxis of Democracy}

Democracy is the slow, painful effort to put right the blunders that we have incorporated into our condition of life. (Konrad 1984:193)

The idea of democracy has grasped the imagination of an overwhelming majority of governments and societies throughout the last century. This process accelerated considerably in the aftermath of WWII, most notably from the mid-1960s. As Alain Touraine noted, most countries have adopted democracy as a common good and this has serious consequences for both the present crisis and the future of democracies worldwide (Touraine 2010). Expectations, and consequently disappointments, about the democratic performance of political parties, national governments and institutions is spreading and growing since the so-called 'third wave' of democratization gained momentum in the 1970s and culminated in 1989.

Thanks to many factors, like the globalization of human rights, the changing geopolitical constellation by the collapse of the Soviet Union and a consequent weakening of the United States concurrent with the transborder emergence of civil society movements and networks, democratic performance is measured now in comparison to its own standards rather than in contrast to non-democratic systems. The disappearance of bipolar logic, the collapse of the ideological, political and the military 'threat of Communism' in Europe left democracies alone with internal problems of legitimation and increasing public expectations. Behind growing expectations, two major driving forces can be identified: 1) the increase of freedom and choice aspirations and 2) the aspirations for the improvement of life chances or simply for human dignity and a sustainable 'good life'. These aspirations are closely intertwined even if they were separated for a long time by mainstream economic and political science theory as well as in the functioning democratic institutions.

There were and still are powerful economic and political interests evident in the daily practice of liberal democracy. Western consumerism and security systems keep this separation intact and alive. The entire modern capitalist world system was built upon this separation and has been functioning and 'developing' accordingly. The tension which arose out of this division produced the dynamics and energy of what we call technical and economic development and innovation, which has both positive and negative consequences. This dynamic became exhausted when the capitalist world system reached its present phase of irreversible imbalance, uncertainty, unpredictability and unmanageability. Although conventional economic and social science theory (still seen by many as 'mainstream') suggests that this is only one of the maybe more serious and destructive crises to be followed by 'business as usual', there are good reasons to believe that the perspectives and possible outcomes will be more severe in the medium and long run. The transformation already began decades ago. The recent eruption and multifarious global manifestations of unprecedented social and political tensions can also be described as a result of this artificially maintained separation. More importantly, they are also manifestations of the accelerating and irreversible global transformation.

Scholars of world system theory and development studies like Immanuel Wallerstein, André Gunder Frank (1980), or Tamás Szentes (2009) have convincingly argued that the modern world system and the global economy today are in a deepening structural crisis and have entered a chaotic, transitional period which will cause a systemic bifurcation and transformation into a new structure, since the system has lost its capacity to rebalance itself. At the same time, the nature of the new structure has not yet been determined and, furthermore, cannot be predetermined (Wallerstein 
2000).

The outbreak of the 2007-2008 global financial and economic turbulence made this crystal clear. Many interdependent social and political dimensions, expectations and demands were revealed in the Arab revolutions and the Occupy! protest movements in the US and later in Europe (Janet Byrne 2012). The decreasing legitimacy and increasing disappointment of voters in 'archeo', democracies (Schmitter 2011), demonstrates that the present system of political and institutional regulations, dominated by century old visions of successful Western European nation-states, and their Westpahlian system of alliances, is not maintainable and has begun to erode. The epoch of Eurocentrism and all-encompassing Western dominance is over.

Instead of leading the $21^{\text {st }}$ century, both the EU and the US are in disarray facing increasingly unmanageable social, economic and political change. Many, often contradictory causes have been put forward for the recent events in the Southern and Eastern European periphery: economic (unemployment and austerity measures), political (institutionalized corruption and failure of education), cultural (religious and ethnic discrimination) or ideological (the return of nationalism). But the most prominent reaction of commentators has been incomprehension. This was and is a major criticism of the Occupy! movements. There is no one political organization directing these insurrections, no single ideology motivating them, no overwhelming demand put forward. The persistent question, 'What do they want?' often leads to the conclusion that the events are not political because they cannot be integrated into existing analytical frameworks. What seems to unite the protesters is simply refusal: 'No more! Enough is enough'. A stubborn negation of the existing system characterized the protests and insurrections. Is this a new type of politics after the decay of democracy? - Insurrection and righteous 'indigNation' (Jensen 2006) as a human immune system response to the reality of a dysfunctional and imbalanced global system which reproduces hierarchy, inequality and polarization? In biology when a bio-system is jeopardized, the system begins to link more of itself to itself. This could be what we are seeing in emerging and expanding networks of protest, like Occupy! and Anonymous and other transnational, global protest movements. It is clear that the response is no longer organized only at the national level, but increasingly at the global level facilitated by technology.

In addition to the indignation and insurrection that results from political invisibility at national levels, unregulated global capitalism can be charged with creating wealth but not effectively distributing it. This is recognized as one of the most destabilizing components of the global crisis (World Economic Forum 2013). In additional, the current system of global capitalism takes no account of what it cannot commodify, neither the social relationships of family and community nor the environment, which are vital to human wellbeing and survival, and indeed to the functioning of the market itself. Ultimately, the increasingly global and interdependent system proves to be progressing towards self-destruction. This circumstance may provoke the criticism of utopian discourse which had its origins in Marxist theory formulated some 150 years ago, but the system has in fact revealed its self-destructive characteristics many times during the long $20^{\text {th }}$ century. It has experienced several severe crises but has successfully recovered by finding ways and means to re-balance itself. There are many signs and good reasons to believe that this is not the case anymore.

The insurrections can be recognized as events of radical change only retrospectively, if the rules of politics change. This depends on who will uphold the possibility of changing the rules of what counts as political. There are certain moments in history when significant change is possible, but changing the system according the 'horizon of desire' or the 'horizon of necessity' (Falk 2012) is not a certainty, only a possibility. In Wallerstein's terms it is only in moments of systemic imbalance during the structural transformation that actors have the most freedom of action, because when a system is well-balanced and operates smoothly, political behavior is determined by the nature of the structure. At moments of transition, individual and collective action become more meaningful, and the transition period to a new structure is more 'open to human intervention and creativity'. These are the moments of 'relative free will' (Wallerstein 2000: 251-252). It is very difficult for any single act or national response to actually set the 'momentum' for change in motion. But when that historical wave arrives, it can be guided. We are in one of those moments now.

In other terms, democracy as we know it needs to be reinvented. Democracy as praxis, as a set of institutions, regulations and legal guarantees defined and confined by the sovereign nation state faces fundamental challenges and is already on the way to deep transformation. At the same time, democracy as an idea has a more profound appeal than the global economic system with its fragmented political units known as 'democracies': it entails the eternal desire of the individual and groups of individuals for freedom and dignity and a greater recognition of the necessity of human cooperation and mutual support and interdependence on a global scale. Saskia Sassen (2006) formulated a similar thought in a slightly different way: 
We have indeed entered a new phase, but we are at its beginning. We don't know what's coming. But I don't think it will be about the national vs. the global. I see, rather, a multiplication of what is beginning to happen today: the formation of partial, often very specialized, assemblages of bits and pieces of territory, of authority, of rights, that used to be lodged in national states. Some of these assemblages will be private, some public, some will continue to inhabit national spaces but be actually denationalized, others will be global. The future we are entering may turn out to be very, very bad, or it may turn out to be reasonable. We don't know, partly because it will be shaped not only by technology and power but also by the dispossessed. The past shows us that history has also been made by the excluded. We can make politics even if we lack power.

\subsection{The Infinite Process of Democratizing Democracy}

Philippe Schmitter (2011) raised a number of highly relevant questions about the future of what he calls the 'REDs', that is, in 'reality existing democracies'. One of his first concerns is that there is little to no consensus among political scientists, experts and practitioners about the definition of democracy. As Larry Diamond formulated it: "defining democracy is a bit like interpreting Talmud (or any religious text): ask a room of ten rabbis (or political scientists) for the meaning, and you are likely to get eleven different answers" (Diamond 2008: 21). Avoiding hopeless academic hurdles of definition, Schmitter talks straight about reality, that is about 'democracies' recognized as such by themselves and by others (mostly by politicians, political scientists and political experts). The number of such entities has increased dramatically during the past half a century which can be seen as a result of both changing values and growing freedom and choice aspirations globally, as well as the consequence of hazy rules and vague and abstract criteria. Except for China, North Korea and perhaps Cuba, very few countries remain that are without aspirations for being called democracies. Even within the explicitly non-democratic, one-party systems there is growing fear about the spread of the spirit of democracy and aspirations for freedom from tyranny. In North Korea, for example, the government suspended university education for an entire academic year and sent students to the countryside to do agricultural work. In China, the Chinese Communist Party tries to control internet usage and banned certain words such as 'Egypt' from search engines.

This opens the way for both almost limitless governmental cynicism and arbitrariness of self-interpretation and for growing popular, bottom-up, self-organizing and mobilizing civil societies and subterranean political and social networks worldwide. The growing gap between aspirations and realities can be interpreted as a 'crisis of democracy'. This leads us to what Schmitter calls the 'great political paradox of our times': at the exact historic moment of the unexpected blossoming of new democratic aspirations in parts of the world seen as hopeless for democratization, old established democracies are facing deepening crises and becoming lost in the turmoil of global and national transformations which they obviously cannot predict, interpret, manage or control efficiently in harmony with each other.

Following the path of Robert Dahl, Schmitter rightly emphasises the ever changing forms and content of democracies in terms of size, scale and scope. Some of these 'revolutionary' changes - like the professionalization of politics or the 'associational revolution' - are recognized and accepted features of democratic regimes, whereas other changes are not yet completely understood or recognized. One of the great challenges is the increasing role, for example, of international 'guardian institutions' such as the World Bank, the IMF, the EU or the European Central Bank. Especially new democracies, often with weak and exposed economies like the post-Soviet, post-Communist countries, can partly be described as 'no choice democracies' by their respected constituencies. Local and national politicians, the only ones who can be made accountable for their decisions, refer to the faraway and unaccountable guardian institutions as leaving them no choices in fundamental decision-making. This tendency has serious and far reaching consequences: first of all, it empties out national sovereignty and delegitimizes democracies on the national level; it supports the general feeling that nobody can be held accountable; and consequently, further strengthens the tendency of growing mistrust of democratic institutions, political parties and politicians.

The decreasing public trust in politics and democratic institutions is a worldwide phenomenon. Although the process of transnational democratization and the establishment of effective and democratic multilevel governance have been held back, the democratization of democracy might gain new momentum. This may be seen with the awakening in MENA countries and the world-wide spread of the spirit and praxis of Occupy! movements followed by the anti-austerity and anti-IMF protests throughout the European peripheries.

The uncontainable Arab Spring had a domino effect throughout the entire Middle East. Unexpected freedom and choice aspirations surfaced one after the other from Tunisia through Egypt, Morocco, Bahrain, Yemen, Jordan, Syria and Libya. The great transformation of the Arab world is far from over and we are certain to face backlash and long 
and painful transformations paradoxical in nature. Political change has not yet crystallized and violence could not be avoided. It is obviously too early to predict the outcome of the eruption of the desire for freedom, but it has been clearly proven that the idea of democracy has an undeniable and growing global appeal and that the democratization of democracy or rather reinvention of democracy is unavoidable.

\section{The Double Democracy Deficit or the European Paradox}

In close connection with the emptying out of democracies and weakening of the nation-state, another important 'revolutionary' change in the scope of democracies is multilevel governance. Obvious failures of the nation-state to cope with global challenges such as terrorism, organized international crime, the escalation of violence, human trafficking, global warming, legal and illegal migration, ageing and overpopulation, increasing poverty and polarization, could be well compensated by introducing new levels of aggregate decision making. This was the case, first of all, in post-WWII Europe where the process of integration produced conceptions and policies that delegated political responsibilities and decision-making on interconnected but distinct sub-national, national and transnational levels.

In the post-1989 euphoria, expectations were high about introducing and empowering new players on the mezo-level. Regional decision-making, however, was taken off the agenda by EU member states pursuing overwhelmingly centralized national interests. Successful efforts of intergovernmentalism have not materialized and nation-states as EU member states could not 'deliver' the expected public goods. This has created a second 'European paradox'. In the case of the European Union, nation-states became new member states of a larger supranational entity, freely delegating decision making and, as a consequence, part of their sovereignty at the supranational level. At the same time, their own democratic legitimacy has been emptied out at home while the new supranational entity is unable to reach full democratic legitimacy.

Voters can only hold their elected politicians accountable at the national level for decisions being brought by the new collective, semi-sovereign (EU) on the supranational level. This discrepancy in the process of European construction of multilevel governance offers the opportunity for national politicians to blame the EU for unpopular decisions which in turn further alienates citizens from EU institutions and undermines public trust in supranational guardian institutions. When EU leaders try and remove European integration from national politics, the EU's legitimacy becomes weaker and calls for more democracy stronger, and space is left open for the emergence of populist parties. The reverse is also possible, as in Italy, Greece and possibly Hungary where a technocratic backlash followed by demands of 'ordo-liberalism' can result in national populism and even extremism. Therefore, the dialectic is rather mutually reinforcing.

There is a tendency among political scientists and analysts of European integration to believe that the EU itself is responsible for the crisis of democracy at the national level. They claim that transnational decision-making weakens the functioning of democratic institutions on the nation-state level and, at the same time, does not lead to automatic democratization at the transnational/European level. There is an undeniable element of truth in this observation. But presumably we need to dig deeper if we want to find the core of the problem and remember where the very roots of creating multinational governance stem from. Jean Monnet emphasized that European democracies have yet to invent and build up a new kind of unprecedented political power. It is up to the capability (or for the time being rather the lack of capability) of European democracies to construct such a unique and unprecedented democratic polity.

Obviously, to create and implement effective multilevel decision making and governance is not an easy job, especially under circumstances of crisis, austerity measures and the erosion of public trust in political institutions. This is a task which requires time and serious and concerted effort, accompanied by political courage, and maybe even just good luck, for stakeholders to seize the right moment to take corrective action. Falling back to the nation-state (or 'state-centric') paradigm will certainly not help to find the right methods for such an unprecedented project, but it might help indirectly by highlighting the limits of the nation-state in an irreversibly globalizing world and therefore open the path for new players, methods and perspectives.

\section{Can the Politics of the Impossible Become the Politics of the Possible?}

Beforehand, the sovereign state was for its subjects an iron cage whence they could communicate legally with the outside world only through narrow bars. Under the pressure of necessities of life, those bars have progressively loosened. The cage is starting to wobble. It will eventually fall to bits. Men will then be able to communicate beyond the frontiers of their respective countries freely and without any hindrance. (Politis: 1927, in Cassese: 2005, p.39). 
It is widely recognized that in the present era of globalization we face "a strong growth of transboundary problems" (Tinnevelt, De Schutter 2011: 1). Although de-territorialisation is not at all a new phenomenon, its intensity has reached a critical level today. It is undeniable that our social existence cannot be reduced to territorially bounded units called nation-states. As Jan Aart Scholte has observed, social and political space "is no longer wholly wrapped in terms of territorial places, territorial distances and territorial borders" (Scholte 1999: 3).

This robust and irreversible tendency poses serious and inevitable questions for both the praxis and theory of democracy. Stepping out from the iron cage of the nation-state, there are no clear answers to questions like: who is responsible to whom? or where are the boundaries of democracy? or, can one imagine democracy without boundaries?

According to a powerful argument made by those who believe we need to reconsider the basic assumptions of conventional democracy theory and consequently the framework and actio radius of democracy, "nation-states are no longer able (...) to guarantee the successful realization of their basic principles of justice and democracy" (Tinnevelt, Schutter 2010: 4).

As a consequence, exposed citizens have to pay for the one-sided decisions of 'sovereign players'. To overcome the democracy deficit of the nation-state paradigm, democracy needs to be expanded and established on the transnational and regional, as well as global level. As global and transnational democracy theorists and activists argue "whoever is affected by a public decision should be included in the democratic process that makes the decision" (Tinnevelt, Schutter 2010: 2). This principle again poses new questions about a transnational, global constituency: who are 'we'? who is able to define who is affected? what kind of common identity supports global/transnational democracy? Must citizens of all kinds of democracies share a common identity, in other words, is it true that a unique identity is the conditio sine qua non of democratic self-determination? can democracy bypass the insider versus outsider, friend versus foe assumption? In other words, can democracy become non-exclusive?

Chantal Mouffe asked a long time ago, "why does every definition of 'we' imply the delimitation of a 'frontier' and the designation of 'them'?" (Mouffe 1993: 84). We won't find clear answers to these profound, new and old, questions rapidly or easily. Most likely blended versions of different forms, frames and content for democracy will emerge on transnational and global levels. The process of hybridization has already begun in global governance (Jensen 2009), but this does not mean that we can predict what shape effective institutions and mechanisms of global governance will take.

The current crisis cannot be overcome by returning to the same principles of free market ideology and austerity measures. The social costs would be too great and there is no logic in trying to reform a system through the same structures and ways of thinking that created the problems and the chaos in the first place. One path or approach to better match financial and economic globalization with effective political globalization might be to increase global political cooperation by constructing ways to facilitate the inclusion of the citizens' concerns (not just elites) in political and economic dialogue and processes.

What can be said with some certainty today is that in order to shape a new global democratic order, without exclusionary politics, the divided parts of democracy, that is, human dignity and human rights on the one hand, wellbeing, 'good life' and economic democracy on the other, need to be reconnected. Although democracy today seems to be lost in the labyrinths of intertwining transformations, at the same time, it is gaining new strength and reinventing itself in unexpected and unorthodox ways. This means that it is not democracy per se or certainly not the idea of democracy that is lost in transformation, but all of those forms, procedures, power structures and political and financial regulations which proved to be unable deliver local, regional and global public goods in an increasingly interdependent and interlinked world. The increasing realization of the existence of de facto transnational, regional and global public goods and the necessity of citizens' concerns sans frontiers may aggregate into an unexpected yet de facto cosmopolitan momentum.

During the past, post-1989 decades, resource-rich actors (guardian institutions, the EU, global philanthropists, among others) have increasingly promoted the notion of civil society, adopting its language and compromising its aspirations with their particular power or profit interests. This conceptual interventionism produced mixed results. It is partly responsible for the global diffusion of the concept of civil society and the widespread debate about it today. Such conceptual interventions are similar to other forms of military, diplomatic or economic interventions that altered the socio-political constellations into which they intervene without being able to predict or control their consequences. The growing discrepancy between words and deeds, between the civil society language used by representatives of the Merchant and the Prince, on the one hand, and the Citizen, a genuine civil society of self-organizing citizens on the other, proved to be a creative confrontation. It is an expression of the growing role of 
civil society in settling global matters.

The pluralistic character and increasing fragmentation and fragility of modern societies demand the further crystallization of new forms of social imagination which is self-reflexive and at the same time self-restricting (Miszlivetz, Jensen 2005). Most importantly, it needs to view all forms of institutionalized democracy as by nature transitory. These forms must always be open to transformation in the future. This approach radically points beyond the way in which democracy is interpreted today, which is essentially elitist and reduced primarily to questions of the rule of law and legality within the boundaries of decreasingly effective political fragments called sovereign national states.

Most democracy theories and theoreticians agree that one of the great and paramount characteristics of democracy is its capacity to renew and even more to re-invent itself. This self-reinvention is not easy or automatic in the context of the perplexities and complexities of the present profound transformation and the diverging expectations and aspirations of decisive players. Nothing remains from the arsenal of the post-WWII economic, legal and social institutions that is incontrovertible. Nation-states, supranational regional institutions, such as the EU, international guardian institutions such as the IMF, the WB or the European Central Bank, not to speak of powerful and unaccountable media empires, seem to be in disarray and are increasingly unable to convince the more attentive, informed and networked global public about their ability to manage, solve and control rapidly changing realities. As the global crisis unfolds, it is less and less possible for these formally unquestionable and formidable players to hide their weaknesses and decreasing legitimacy. Public trust is today at its lowest level concerning economic, political and legal institutions, be they on the national, regional or global level. Both markets and democratic legal-political institutions are made by human beings and are reflections of public and individual needs, expectations and trust. If this complex consensus and respect which legitimates their existence and functioning is seriously eroded, they become dysfunctional, redundant and sooner or later disintegrate. Except for some nation-states, most of these players were created after WW II as economic, political, legal, and institutional guarantees of democracy and even a democratic world order. These partly imagined, partly real guarantees have seriously eroded and evaporated today. We have arrived at a stage where we need a new, inclusive and decisive debate about different possible interpretations, meanings, and institutions of democracy on all possible levels. The process of deliberation and redefinition will be neither rapid nor without conflicts. The harmonization of regulations and interests on global, regional and local levels is rather a politically correct slogan than a reality today.

The 'fourth wave' of democratization that started with the revolutions in the Arab world has resulted in a major shift of focus in interest and action. Democracy has received an irreversibly global dynamic, initiated and led by unexpected actors who were almost completely out of the scope of democracy debates and discourse dominated by politics, media and other institutions of the West. Since many Western democracies have become or are becoming 'no choice democracies' and therefore loosing their legitimacy, democracy is out of joint in the Western world; meanwhile, the idea of democracy, the spirit of freedom and dignity, is rapidly and unexpectedly spreading in 'impossible' regions. This global stretch of the boundaries of possible democratizations not only heralds the end of a set of Western prejudices and racist conceptualizations such as the 'clash of civilizations'. It also requires new methods and approaches to dialogue and analysis. In a conventional sense, following the conventional state-centric paradigm, it might be true that democracy assumes congruence between the state, the people and the territory. But facing the realities of the 21 st century, such as the formidable increase of migration, the uncontrollable global financial capital flows, the unaccountability of international and domestic guardian institutions, we need to find new configurations for matching the expectations of an increasingly de-territorialized and growing global public. This might be the historic moment when cosmopolitanism becomes everyday practice, moving from its status as a utopia of wishful thinkers, visionary intellectuals and marginalized groups, to a viable de facto option for upcoming generations clamoring for rights in a global public space.

The growing tension between the 'horizon of feasibility', the 'horizon of necessity' and the 'horizon of desirability' might give birth to new approaches to reality and to new, unexpected ('impossible') agents of political change. These new actors - be they crossborder networks of civil initiatives, concerned professionals, independent investigative journalists, Occupy! activists or human rights movements and student organizations operating via social media combined with street demonstrations, conglomerates of cities and universities or individuals identified as 'cultural creatives' - in alliance and collaboration with each other might push further the boundaries of the possible. They are already crossing outdated political and ideological boundaries as well as the boundaries of sovereign nation-states and they may have the potential to turn the 'politics of the impossible' into a new 'politics of the possible'. 


\section{References}

Archibugi, Daniele, \& Guido Montani. (eds.) (2011). European Democracy and Cosmopolitan Democracy. The Ventotene Papers. The Altiero Spinelli Institute for Federalist Studies. Pavia, Italy.

Beck, Ulrich. (2006). Cosmopolitan Vision. Cambridge: Polity Press.

Blokker, Paul. (2009). Democracy Through the Lenses of 1989: Liberal Triumph or Radical Turn? International Journal of Politics, Culture and Society, 22(2), 273-290.

Byrne, Janet. (ed.) (2012). The Occupy Handbook. New York, Boston, London: Back Bay Books, Little, Brown and Company.

Cassese, Antonio. (2005). International Law. Cambridge: Oxford University Press.

Diamond, Larry. (2008). The Spirit of Democracy. New York: Holt.

Diamond, Larry. (2010). Why Are There No Arab Democracies? Journal of Democracy, 21(1), 93-105. http://dx.doi.org/10.1353/jod.0.0150

Falk, Richard. (2012). Can We Overcome the Global Crisis: Obstacles, Options and Opportunities. Unpublished manuscript.

Frank, André Gunder. (1980). Crisis: in the World Economy. London: Heinemann.

Gilbert, Jeremy. (2009). Postmodernity and the Crisis of Democracy. Open Democracy (28 May).

Holton, Robert. (2012). Culture, Politics, and the Global Financial Crisis. The European Financial Review (20 October). [Online] Available: http://www.europeanfinancialreview.com/?s=Holton +2010

Hurrell, A. (1995). International Political Theory and the Global Environment. In Booth, Ken and Steve Smith (Eds.), International Relations Theory (pp. 129-153). Cambridge: Polity.

Jensen, Jody. (2006). The Social Costs of a Lumpen Political Class. Találjuk-ki Közepeuropa [Reinventing Central Europe]. [Online] Available: www.talaljuk-ki.hu

Jensen, Jody. (2009). Whose Rules? Globalizing Governance in a Multistakeholder World. Saarbrucken: Lambert Academic Publishing.

Kaldor, Mary, Held, \& David Quah, Danny. (2010). The Hydra-Headed Crisis. Global Policy Journal (28 February). [Online] Available: www.globalpolicyjournal.com/articles/global-governance/hydra-headed-crisis

Konrad, György. (1984). Antipolitics: An Essay. London: Quartet.

Miszlivetz, Ferenc, \& Jody Jensen. (2005). The Languages of Civil Society - Europe and Beyond. EUI Working Paper. Badia Fiesole: European University Institute (May).

Miszlivetz, Ferenc. (2010). 'We are in a Situation of Relative Free Will,' Interview with Immanuel Wallerstein. Society and Economy, 32. http://dx.doi.org/10.1556/SocEc.32.2010.1.10

Miszlivetz, Ferenc. (2012). The Multiple Crisis of Europe. In, Léonce Bekemans (Ed.), A Value-Driven European Future (pp159-181). Peter Lang.

Mouffe, Chantal. (1993). The Return of the Political. London, New York: Verso.

Nerfin, Marc. (1987). Neither Prince, nor Merchant: Citizen - An Introduction to the Third System. Development Dialogue, (1), 170-195.

Offe, Claus, \& Jeremy Gaines. (1996). The Varieties of Transition: The East European and East German Experience. Cambridge: Polity Press.

Posner, Richard A. (2010). The Crisis of Capitalist Democracy. Harvard University Press. Cambridge: Harvard University Press.

Preuss, Ulrich. (2001). The Rulemaking and Policy Actors in the Transition and the Issue of the Strategy of Transformation. Studies in East European Thought, 53, 183-195. http://dx.doi.org/10.1023/A:1011206817748

Reich, Robert. (2008). Supercapitalism: The Transformation of Business, Democracy and Everyday Life. New York: Knopf.

Sassen, Saskia. (2006). Denationalized States and Global Assemblages. Eurozine (11 November). [Online] Available: http://www.eurozine.com/articles/2006-11-20-sassen-en.html 
Schmitter, Philippe C. (2011). The Future of Real-Existing Democracies. Society and Economy, 33(2), 399-428. http://dx.doi.org/10.1556/SocEc.33.2011.2.9

Scholte, Jan Aart. (1999). Global Civil Society: Changing the World? Centre for the Study of Globalisation and Regionalisation, Working Paper No. 31. Coventry: University of Warwick.

Stiglitz, Joseph. (2010). The Stiglitz Report. Reforming the International Monetary and Financial Systems in the Wake of the Global Crisis. New York: The New Press.

Szentes, Tamás. (2009). Ki, mi, és miért van válságban? [Who, What and Why is in Crisis?]. Budapest: Napvilág Kiadó, CRITICA.

Tinnevelt, Ronald, \& De Schutter, Helder. (eds.) (2010). Global Democracy and Exclusion. Chichester: Wiley-Backwell. http://dx.doi.org/10.1002/9781444328288

Touraine, Alain. (2010). Strong Democracy to Cope with Economic Crisis. Speech delivered at the Parliamentary Assemby of the Council of Europe (21 June).

Wallerstein, Immanuel. (2000). Globalization or the Age of Transition? - A Long Term View of the Trajectory of the World System. International Sociology, 15(2), 251-267. http://dx.doi.org/10.1177/0268580900015002007

World Economic Forum. (2013). Global Risks 2013. [Online] Available: http://reports.weforum.org/global-risks-2013.

Note

Note 1. A fourth powerful player, the Media, should be added to the list as the 'Magician'. 